\title{
THE EFFECT OF STOCKING DENSITY ON CERTAIN BROILER WELFARE PARAMETERS **
}

\author{
Z. Škrbić ${ }^{*}$, Z. Pavlovski1 ${ }^{1}$ M. Lukić ${ }^{1}$, L. Perić ${ }^{2}$, N. Milošević \\ ${ }^{1}$ Institute for Animal Husbandry, Belgrade-Zemun \\ ${ }^{2}$ Agriculture faculty, Novi Sad \\ * Corresponding author: \\ Zdenka Škrbić; e-mail: zdskrbic@yahoo.com \\ ${ }^{* *}$ Original scientific paper
}

\begin{abstract}
In broiler production, stocking density, i.e. floor surface per chicken, is very important welfare factor which directly and indirectly influences and determines the level of growth of chicken body weight, but it is also related to other welfare indicators. Objective of the paper was to define the broiler welfare in different stocking densities by evaluation of their walking ability (gait score), feathering, incidence and degree of hock burns, foot pad lesions, and by determination of the biochemical blood parameters (glucose concentration, total cholesterol concentration), as indicators of condition of stress. One day old chickens of Hubbard genotype were housed in boxes in floor rearing system, in 3 stocking densities and 5 repetitions of each treatment. Treatment A scored stocking density of $10 \mathrm{birds} / \mathrm{m}^{2}$; treatment B, $13 \mathrm{birds} / \mathrm{m}^{2}$ and treatment $\mathrm{C}, 16 \mathrm{birds} / \mathrm{m}^{2}$. Results of the trial indicate absence of significance of differences between trial groups of broilers in regard to their walking ability, condition of skin and legs, and stress indicators. In general, broiler welfare in all trial groups was satisfactory. However, determined tendencies of worsening of the condition of litter, increase of the frequency of lower scores for walking ability (gait score), hock burns and foot pad lesions which occur with increase of stocking density, indicate the importance of this rearing factor and need to define limiting stocking densities from the aspect of broiler welfare but also economical efficiency of production.
\end{abstract}

Keywords: broilers, stocking density, welfare.

\section{Introduction}

Awareness of the welfare of intensive poultry production started to develop about 30 years ago in North European countries and was primarily focused on cage system of rearing of layer hens. Subsequently regulations were 
laid down on national and international level which banning the cage system and defining production systems based on "friendly", human relation to animals. Welfare of farm animals is very important from the aspect of perception of the quality of product by consumers which have the point of view that preservation of high welfare standards results in high quality of the product (Sundrum, 2001). This contributes to increasing interest in evaluation and improvement of broiler welfare in different rearing conditions and management systems.

In broiler production, stocking density, i.e. floor surface per chicken, is very important welfare factor. Namely, minimal standards in relation to welfare of broilers are focused on space for their walking which is the main prerequisite for development of the locomotive apparatus and demonstration of basic forms of behavior (Directive 2007/43/CE).

There are many papers on the effect of stocking density on production of broilers as welfare indicator, and very wide scope of stocking densities was investigated. Most of the researches included stocking density of 20 to 40 $\mathrm{kg} / \mathrm{m}^{2}$. In general, trend of decrease of the level of growth with the increase of stocking density in the floor system was established (Lewis et al. 1997, Mortari et al. 2002, Dozier et al. 2005, Škrbic 2007), as consequence of heat stress (Yadgari et al. 2006), main factor of growth depression in cases of high stocking densities.

The second group of welfare indicators relates to condition of skin (dermatitis, lesions, injuries) and legs. Whereas research results by Sorensen et al. (2000), Garcia et al. (2002) indicate that different forms of dermatitis, breast blister, weakness of legs, are responses to stocking density, certain authors (Elwinger, 1995; Thaxton et al., 2006) state that stocking density in numerous cases is no direct cause of incidence of such damages, but factors relating to stocking density and define them as factors of farm and season.

Third group of physiological parameters relates to incidence of physiological adaptive changes which indicate the stress. Thaxton and Puvadolpirod (2000) defined 10 adaptive changes in conditions of stress which among others relate to level of plasma corticosterone, glucose concentration, cholesterol concentration in plasma, leukocyte number, etc.

Subject of this research was to define certain parameters of welfare in different broiler ages, as well as effect of applied stocking densities in intensive production conditions.

\section{Material and methods}

Trial was carried out in the facility with floor system of rearing and controlled environment conditions. Total of 1500 one day old chickens of 
Hubbard genotype was placed into boxes of floor system of rearing in 3 stocking densities and 5 repetitions of each treatment. Treatment $\mathrm{A}$ designated stocking density of $10 \mathrm{birds} / \mathrm{m}^{2}$; treatment B, 13 birds $/ \mathrm{m}^{2}$ and treatment $\mathrm{C}, 16$ birds $/ \mathrm{m}^{2}$, i.e. in each box of surface of $7.7 \mathrm{~m}^{2} 77,100$, and 123 chickens were housed, respectively. For litter chopped straw was used. Continuous light regime during $24 \mathrm{~h}$ was applied. All of the chickens had adequate feeding and watering space, Nutrition was ad libitum with 4 mixtures formulated based on corn/soy bean.

Control of the body weight of chickens was carried out on the first day (average $41.8 \mathrm{~g}$ ), on $21^{\text {st }}$ day and at the end of the trial, at the age of 42 days. Welfare parameters were determined at the age of 21 and 42 days, except the evaluation of the feathering which was done only at the age of 21 days and physiological parameters of welfare determined at the age of 42 days.

Walking ability was scored according to method by Kestin et al. (1992). Gait score designates six categories of walking ability ranked from 0 (completely normal) to 5 (immobile), described in the paper by Thomas et al. (2004). In the same paper the method is described based on which the hock burns on chickens were determined: score $1=$ no burns; score 2 = mild burns; score 3 = severe burns. Feather cover of chickens was evaluated at the age of 21 days according to the method of Gyles et al. (1962) adjusted to changes in body weight and breast width of modern broiler hybrids. Each bird was stoked over the keel with the palm of the hand in an anterior posterior direction and the amount of flesh showing through the pressed feathers was scored on the three point scale: 1 = relatively large amount of skin showing; 2 = medium amount of skin showing and $3=$ almost complete feather cover with small amount of skin showing (Perić et al., 2007). Foot pad lesions were scored using the three point scale (Thomas et al., 2004): score 1 = no lesions; score 2 = mild lesions; score 3 $=$ severe lesions.

For the purpose of determination of the quality of litter, temperature of litter was measured on the $21^{\text {st }}$ and $42^{\text {nd }}$ day, on three measuring locations/points in the box and in this way average temperature of litter for box as experimental unit was obtained. At the end of trial, in the same way, samples of litter were taken for determination of the moisture content, by method of drying of samples on $105^{\circ} \mathrm{C}$ to constant weight.

At the end of trial, on random sample of 20 chickens per treatment and determined by sex, blood samples were taken for the purpose of determination of biochemical parameters, i.e. glucose concentration (spectral-photometry, GOD-PAP) and total cholesterol (spectral-photometry, PAP).

Data was analyzed by method of variance analysis and Tukey test (Stat.Soft,Inc. STATISTICA, version 6). Beside presented average values of evaluations, and for the purpose of more complete consideration of the situation 
in regard to broiler welfare in trial groups, also frequencies of chickens with certain evaluation of the incidence of investigated welfare indicators are presented.

\section{Results and discussion}

As it can be seen from the table 1, there was no significant effect of stocking density on weight of chickens at the age of 3 weeks. However, in the second weighing at the age of chickens of 6 weeks, a tendency of increase of final body weightes with the decrease of the stocking density can be concluded with confirmed significance of the investigated effect, in accordance with results obtained by other authors (Mortari et al., 2002; Dozier et al., 2006; Škrbić 2007) and indicates higher importance of this rearing factor in final stages of production cycle.

Table 1. Body weight of chickens in investigated stocking densities at the age of 3 and 6 weeks

\begin{tabular}{|c|c|c|c|}
\hline \multirow{2}{*}{ Parameter } & \multicolumn{3}{|c|}{ T R E A T M E N T } \\
\hline & $\bar{A}$ & $\mathrm{~B}$ & $\mathrm{C}$ \\
\hline \multicolumn{4}{|c|}{ Body weight (g) } \\
\hline $\mathrm{n}$ & 199 & 255 & 323 \\
\hline 3 weeks & $828.34 \pm 65.93$ & $836.31 \pm 68.77$ & $837.68 \pm 73.14$ \\
\hline 6 weeks & $2474.92 \pm 294.52^{\mathrm{A}}$ & $2435.33 \pm 287.29^{\mathrm{AB}}$ & $2383.53 \pm 300.64^{\mathrm{B}}$ \\
\hline
\end{tabular}

Value expressed as $x \pm \mathrm{Sd}$;

${ }^{\text {A-B }}$ Values within the row without same letters are significantly different $(\mathrm{p}<0.01)$

Gait score represents subjective method of evaluation of the walking ability of chickens. Established differences in average values of gait score (table 2) between groups of chickens of both ages were bellow the limit of statistical importance which further induces the conclusion that housing of chickens in lower density (10 compared to $16 \mathrm{birds} / \mathrm{m}^{2}$ ) doesn't lead to improvement of the walking ability. However, it must be taken into consideration that in general there were no problems with walking of chickens in any of the groups, which can have influence if we made the right conclusion. Frequency of certain scores per groups, however, indicates certain effect of the stocking density, as well as the age which reflects the effect of body weight of chickens on the ability to walk. Chickens at the age of 3 weeks in groups A and B weren't given scores bellow 2 which means that there were no serious problems in relation to their maneuver abilities and speed. However, in group of higher stocking density (C), in $2.78 \%$ of evaluated chickens a significant disorder of walking was registered. In the same group but at the age of 6 weeks, $4 \%$ of evaluated 
chickens were immobile. Main cause is physical inactivity of chickens as consequence of lack of space in higher stocking density and genetic predisposition for high final body weights which are in disharmony with the development of the locomotive apparatus (Sanotra et al., 2001; Petersen, 2004).

Table 2. Impact of stocking density on the gait score of broilers at 3 and 6 weeks of age

\begin{tabular}{|c|c|c|c|c|c|c|c|c|}
\hline \multirow{2}{*}{ Treatment } & \multirow{2}{*}{$\mathrm{n}$} & \multirow{2}{*}{$\begin{array}{l}\text { Average } \\
\text { gait score }\end{array}$} & \multicolumn{6}{|c|}{ Frequency, \% } \\
\hline & & & 0 & 1 & 2 & 3 & 4 & 5 \\
\hline \multicolumn{9}{|l|}{3 weeks } \\
\hline A & 36 & 0.27 & 76.92 & 19.23 & 3.85 & 0 & 0 & 0 \\
\hline $\mathrm{B}$ & 36 & 0.33 & 72.22 & 22.22 & 5.56 & 0 & 0 & 0 \\
\hline $\mathrm{C}$ & 36 & 0.47 & 66.66 & 25.00 & 5.56 & 0 & 2.78 & 0 \\
\hline \multicolumn{9}{|l|}{6 weeks } \\
\hline $\mathrm{A}$ & 36 & 0.35 & 70.27 & 24.32 & 5.41 & 0 & 0 & 0 \\
\hline $\mathrm{B}$ & 36 & 0.47 & 68.75 & 21.87 & 6.25 & 0 & 3.13 & 0 \\
\hline C & 36 & 0.68 & 48.00 & 48.00 & 0 & 0 & 0 & 4.00 \\
\hline
\end{tabular}

Results of the incidence of hock burns and foot pad lesions, which were evaluated at the same time are presented in table 3. Based on average values of the evaluation of the incidence and severity (degree) of the hock burns and foot pad lesions, good condition in all chicken groups and ages can be concluded. Frequency of certain scores for hock burns in the $6^{\text {th }}$ week of age however suggests the tendency of increase of number of chickens with serious ankle inflammations with the increase of stocking density, which is result of contact with fresh, coarse litter over longer period of time which chickens sped in the rest period (lying). Broilers spend during day approx. 76-86\% of total time lying. In conditions of higher stocking density, as well as with the age, i.e. increase of the body weight, this percentage reaches the top limit (Weeks et al., 2000). 
Table 3. Impact stocking density on the incidence of hock burns and foot pad esions of broilers at 3 and 6 weeks of age

\begin{tabular}{|c|c|c|c|c|c|}
\hline \multirow{2}{*}{ Treatment } & \multirow{2}{*}{$\mathrm{n}$} & \multirow{2}{*}{$\begin{array}{c}\text { Average } \\
\text { score }\end{array}$} & \multicolumn{3}{|c|}{ Frequency, $\%$} \\
\hline & & & 1 & 2 & 3 \\
\hline \multicolumn{6}{|l|}{$\begin{array}{l}\text { Hock burns } \\
3 \text { weeks }\end{array}$} \\
\hline $\mathrm{A}$ & 54 & 1.04 & 96.30 & 3.70 & 0 \\
\hline $\mathrm{B}$ & 49 & 1.03 & 97.44 & 2.56 & 0 \\
\hline $\mathrm{C}$ & 46 & 1.00 & 100.00 & 0 & 0 \\
\hline \multicolumn{6}{|l|}{6 weeks } \\
\hline $\mathrm{A}$ & 47 & 1.01 & 97.30 & 2.70 & 0 \\
\hline $\mathrm{B}$ & 46 & 1.08 & 86.11 & 13.89 & 0 \\
\hline $\mathrm{C}$ & 46 & 1.15 & 80.56 & 19.44 & 0 \\
\hline \multicolumn{6}{|c|}{$\begin{array}{l}\text { Foot pad lesions } \\
3 \text { weeks }\end{array}$} \\
\hline $\mathrm{A}$ & 54 & 1.02 & 98.15 & 1.85 & 0 \\
\hline $\mathrm{B}$ & 49 & 1.00 & 100.00 & 0 & 0 \\
\hline $\mathrm{C}$ & 46 & 1.00 & 100.00 & 0 & 0 \\
\hline \multicolumn{6}{|l|}{6 weeks } \\
\hline $\mathrm{A}$ & 47 & 1.00 & 100.00 & 0 & 0 \\
\hline $\mathrm{B}$ & 46 & 1.00 & 100.00 & 0 & 0 \\
\hline $\mathrm{C}$ & 46 & 1.00 & 100.00 & 0 & 0 \\
\hline
\end{tabular}

Control of feathering of broiler was carried out at the age of 3 weeks (table 4) considering that this process was finished at the age of 6 weeks. Poor feathering can be predisposition for incidence of different skin lesions. Differences between trial groups in average evaluation/score for feathering were small and without statistical significance.

Table 4. Effect of stocking density on feathering in broilers at 3 weeks of age

\begin{tabular}{|c|c|c|c|c|}
\hline \multirow{2}{*}{ Treatment } & \multirow{2}{*}{$\begin{array}{c}\text { Average } \\
\text { score }\end{array}$} & \multicolumn{3}{|c|}{ Frequency, \% } \\
\cline { 3 - 5 } & 1.91 & 37.04 & 2 & 3 \\
\hline $\mathrm{A}$ & 1.56 & 58.98 & 41.02 & 0 \\
\hline $\mathrm{B}$ & 1.97 & 39.13 & 50.00 & 10.87 \\
\hline $\mathrm{C}$ & \multicolumn{3}{|c|}{} \\
\hline
\end{tabular}

Also, based on frequency of scores for feathering in trial groups the effect of investigated stocking densities cannot be clearly determined. Elwinger (1995) states that stocking density has no effect on chicken feathering as one of the indicators of health condition of chickens. Relatively limited effect of stocking density on environment conditions and indirectly on health condition of broilers, is explained by strict control of microclimatic conditions in modern 
systems for ventilation/air quality and heating in most of the facilities included in the research.

Quality of litter in trial groups, expressed through average temperature and moisture content, is presented in table 5. Clearly, by increase of stocking density also the content of moisture and temperature of litter increase, i.e. in general its quality is worsening. Similar results are stated by Elwinger (1995), Dozier et al. (2005), Dozier et al. (2006), Mendes et al. (2004), who point out also the importance of season. At the same time with the increase of temperature and moisture content, also physical and microbiological characteristics of litter change, which are important in relation to incidence of contact dermatitis caused by bacterial infections, especially Staphylococcus aureus and Escherichia coli (Butterworth, 1999). However, correlation between the moisture content of the litter and incidence of serious foot-pad dermatitis cases was not statistically significant in the research by Eichner et al. (2007), which is in accordance with our research results, which indicate to the conclusion that for incidence of foot pad dermatitis other factors are also important, such as type of litter, nutrition factors, growth dynamics, etc. (Petersen, 2004).

Table 5. Average temperature and moisture content of litter in investigated stocking densities

\begin{tabular}{|c|c|c|c|}
\hline \multirow{2}{*}{ Treatment } & \multicolumn{2}{|c|}{ Average temperature, ${ }^{\circ} \mathrm{C}$} & \multirow{2}{*}{$\begin{array}{l}\text { Average moisture content (\%) } \\
\text { in } 6 \text { week }\end{array}$} \\
\hline & 3 weeks & 6 weeks & \\
\hline A & 21.75 & 29.66 & 42.49 \\
\hline B & 22.50 & 30.83 & 49.59 \\
\hline $\mathrm{C}$ & 22.67 & 31.83 & 54.76 \\
\hline
\end{tabular}

Presented results of the biochemical blood parameters (table 6) are without statistically significant differences between trial groups and indicate the conclusion that from the physiological aspect there was no difference in broiler welfare in investigates stocking densities. Similar results are stated by Dozier et al. (2006), Thaxton et al. (2006) and conclude that stocking densities between 30 and $45 \mathrm{~kg} \mathrm{BW} / \mathrm{m}^{2}$ to 49 days of age do not represent causes of stress. Established concentrations of glucose and total cholesterol in blood of broilers from trial groups were within limits of reference values. Glucose concentration was slightly higher than the value stated by Pavkov et al. (1998) for control group, whereas it is in accordance with results of Kanački et al. (2008). Rusov (2002) states explicit need of birds for this quick accessible source of energy which is in their blood in the double concentration compared to blood from mammals, which is in accordance with presented results. 
Table 6. Biochemical parameters of blood from broilers at the age of 42 days

\begin{tabular}{|c|c|c|}
\hline Treatment & $\begin{array}{l}\text { Glucose conc., } \\
\mathrm{mmol} / 1\end{array}$ & $\begin{array}{l}\text { Total cholesterol conc., } \\
\mathrm{mmol} / 1\end{array}$ \\
\hline A & $10.74 \pm 0.57$ & $2.36 \pm 0.23$ \\
\hline B & $11.23 \pm 1.03$ & $2.41 \pm 0.40$ \\
\hline $\mathrm{C}$ & $10.71 \pm 0.77$ & $2.65 \pm 0.28$ \\
\hline & & \\
\hline $\mathrm{A}$ & $10.56 \pm 0.32$ & $2.40 \pm 0.19$ \\
\hline $\mathrm{B}$ & $11.52 \pm 0.41$ & $2.42 \pm 0.16$ \\
\hline $\mathrm{C}$ & $10.68 \pm 0.81$ & $2.74 \pm 0.29$ \\
\hline \multicolumn{3}{|c|}{ 웅 } \\
\hline $\mathrm{A}$ & $10.92 \pm 0.74$ & $2.32 \pm 0.29$ \\
\hline $\mathrm{B}$ & $10.94 \pm 1.42$ & $2.40 \pm 0.58$ \\
\hline $\mathrm{C}$ & $10.74 \pm 0.81$ & $2.56 \pm 0.27$ \\
\hline
\end{tabular}

\title{
Conclusion
}

Based on established indices it can be concluded in general that reduction of stocking density from 16 to 13 , i.e. $10 \mathrm{birds} / \mathrm{m}^{2}$ in intensive broiler production doesn't have significant effect on main broiler welfare parameters, which relate to the walking ability, incidence and degree of hock burns, foot pad lesions and feathering. Absence of physiological adaptive changes in broilers from every trial group contributes to this conclusion, which eliminates the condition of stress in investigated stocking densities.

However, determined tendencies of worsening of the quality of litter, increase of frequency of poor scores for walking ability (gait score), hock burns and foot pad lesions with the increase of stocking density, indicate the importance of this factor of rearing and need to define limiting stocking densities in our climatic and production conditions from the aspect of broiler welfare but also economical efficiency of production.

\section{UTICAJ GUSTINE NASELJENOSTI NA POJEDINE PARAMETRE DOBROBITI BROJLERA}

\author{
Z. Škrbić, Z. Pavlovski, M. Lukić, L. Perić, N. Milošević
}

\section{Rezime}

U brojlerskoj proizvodnji gustina naseljenosti, odnosno površina poda po piletu, je veoma važan faktor dobrobiti koji svojim direktnim i indirektnim uticajima određuje nivo porasta telesne mase pilića ali se dovodi u vezu i sa 
drugim indikatorima dobrobiti. Cilj rada je bio definisanje dobrobiti brojlera u različitim gustinama naseljenosti ocenom sposobnosti kretanja (gait score), operjalosti, pojave i stepena zapaljenja kože zgloba, lezije na jastučiću stopala i utvrđivanjem biohemijskih parametara krvi (koncentracija glukoze, koncentracija ukupnog holesterola) kao pokazatelja stanja stresa. Jednodnevni pilići genotipa Hubbard su razmešteni u bokseve podnog sistema gajenja u 3 gustine naseljenosti i 5 ponavljanja svakog tretmana. Tretman A je označavao gustinu naseljenosti $10 \mathrm{grla} / \mathrm{m}^{2}$; tretman $\mathrm{B}, 13 \mathrm{grla} / \mathrm{m}^{2}$ i tretman $\mathrm{C}, 16 \mathrm{grla} / \mathrm{m}^{2}$. Rezultati ogleda ukazuju na nesignifikantnost razlika oglednih grupa brojlera u pogledu sposobnosti kretanja, stanja kože i nogu, indikatora stresa. Generalno, dobrobit brojlera u svim oglednim grupama je bila zadovoljavajuća. Međutim, utvrđene tendencije pogoršanja kvaliteta prostirke, povećanja frekvencije lošijih ocena sposobnosti kretanja (gait score), zapaljenja kože zgloba i lezije na jastučiću stopala sa povećanjem gustine naseljenosti, ukazuju na značaj ovog faktora gajenja i potrebu definisanja limitirajućih gustina naseljenosti sa aspekta dobrobiti brojlera ali i ekonomičnosti proizvodnje.

Ključne reči: brojleri, gustina naseljenosti, dobrobit

\section{ACKNOWLEDGEMENTS}

This research is part of the Project EVB: TR-20021 financial supported by Ministry of Science and Technological Development of the Republic of Serbia.

\section{References}

BUTTERWORTH A. (1999): Infectious components of broiler lameness: A review. World's Poultry Science Journal, 55, 327-352.

Directive 2007/43/CE).

http://ec.europa.eu/food/animal/welfare/farm/broilers en.htm

DOZIER W.A., THAXTON J.P., BRANTON S.L., MORGAN G.W., MILES D.M., ROUSH W.B., LOTT B.D., VIZZIER-THAXTON Y. (2005): Stocking Density on Growth Performance and Processing Yields of Heavy Broilers. Poultry Science, 84: 1332-1338.

DOZIER W.A., THAXTON J.P., PURSWELL J.L., OLANREWAJU H.A., BRANTON S.L., ROUSH W. B. (2006): Stocking Density Effects on Male Broilers Grown to 1,8 Kilograms of Body Weight. Poultry Science, 85: 344351.

EICHNER G., VIEIRA S.L., TORRES C.A., CONEGLIAN J.L.B., FREITAS D.M., OYARZABAL O.A. (2007): Litter Moisture and Footpad dermatitis as 
affected by Diets Formulated on an All-Vegetable Basis or Having the Inclusion of Poultry By-Product. Journal of Applied Poultry research, 16, 344-350.

ELWINGER K. (1995): Broiler production under varying population densitiesA field study. Archiv für Geflügelkunde, 59 (4), 209-215.

GARCIA R.G., MENDES A.A., GARCIA E.A., NÄÄS I.A., MUREIRA J., ALMEIDA I.C.L., TAKITA T.S. (2002): Effect of Stocking Density and Sex on Feathering, Body Injury and Breast Meat Quality of Broiler Chickens. Revista Brasileria de Ciência Avicola, 40(1).

GYLES N.R., KAN J., SMITH R.M. (1962): The heritability of breast blister condition and breast feather coverage in a White Rock broiler strain. Poultry Science, 42, 13-17.

KANAČKI Z., KRNIĆ J., UŠĆEBRKA G., PERIĆ L., STOJANOVIĆ S. (2008): Uticaj različitih izvora selena u ishrani tovnih pilića na pojedine proizvodne i biohemijske parametre. Savremena poljoprivreda, 57, 1-2, 160-165 KESTIN S.C., KNOWLES T.G, TINCH A.E., GREGORY N.G. (1992): Prevalence of leg weakness in broiler chickens and relationship with genotype. Veterinary Record, 131, 190-194.

LEWIS P.D., PERRY G.C., FARMER L.J., PATTERSON R.L.S. (1997): Responses of Two Genotypes of Chicken to the Diets and Stocking Densities Typical of UK and "Label Rouge" Production Systems: 1. Performance, Behaviour and Carcass Composition. Meat Science, 45, 4, 501-516.

MENDES A.A., GARCIA R.G., IMEIDA I.C.L.A., MOREIRA J. (2004): Effect of stocking densities and season on performance, environmental and thermoregulatory parameters and carcass yield of broiler chickens. XXII World's Poultry Congress, Istanbul-Turkey, 8-13 June 2004, Book of abstracts, 417 (Fulltext CD).

MORTARI A.C., ROSA A.P., ZANELLA I., NETO C.B., VISENTIN P.R., BRITES L.B.P. (2002): Performance of broilers reared in different population density, in winter, in South Brazil. Ciência Rural 32(3).

PAVKOV S., KOSTADINOVIĆ Lj., KOVAČEVIĆ M. (1998): Hematološki i biohemijski parametri brojlera pri preventivnom tretmanu salinomicinom i amproliumom. Nauka u živinarstvu 3, 1-2, 145-151.

PERIC L., NOLLET L., MILOSEVIC N., ZIKIC D. (2007): Effect of Bioplex and Sel-Plex substituting inorganic trace mineral sources on performance of broilers. Archiv für Geflügelkunde, 71, 3, 122-129.

PETERSON J.S. (2004): Management and housing systems for broilers Effects on welfare and production. XXII World's Poultry Congress, IstanbulTurkey, 8-13 June 2004, Book of abstracts, 325 (Fulltext CD).

RUSOV Č. (2002): Hematologija ptica. Naučni institut za veterinarstvo, Beograd.

SANOTRA G.S., LUND J.D., VESTERGAARD K.S. (2002): Influence of light-dark schedules and stocking density on behaviour, risk of leg problems 
and occurrence of chronic fear in broilers. British Poultry Science, 43, 3, 344354.

ŠKRBIĆ Z. (2007): Efekti gustine naseljenosti i svetlosnog programa na proizvodne i klanične osobine brojlerskih pilića različitog genotipa. Doktorska disertacija. Poljoprivredni fakultet, Beograd.

SORENSEN P., SU G., KESTIN S.C. (2000): Effects of Age and Stocking Density on Leg Weakness in Broiler Chickens. Poultry Science, 79, 864-870.

SUNDRUM A. (2001): Organic livestock farming - a critical review. Livestock Production Science, 67, 3,207-215.

THAXTON J.P. and PUVADOLPIROD S. (2000): Model of physiological stress in chickens. 5.Quantitative evaluation. Poultry Science 79, 391-395. THAXTON J.P., DOZIER III W.A., BRANTON S.L., MORGAN G.W., MILES D.W., ROUSH W.B., LOTT B.D., VIZZIER-THAXTON Y. (2006): Stocking Density and Physiological adaptive Responses of Broilers. Poultry Science, 85, 819-824.

THOMAS D.G., RAVINDRAN V., THOMAS D.V., CAMDEN B.J., COTTAM Y.H., MOREL P.C.H., COOK C.J. (2004): Influence of stocking density on the performance, carcass characteristics and selected welfare indicators of broiler chickens. New Zealand Veterinary Journal, 52, 76-81.

WEEKS C.A., DANBURY T.D., DAVIES H.C., HUNT P., KESTIN S.C. (2000): The behaviour of broiler chickens and its modification by lameness. Applied animal Behaviour Science, 67, 111-125.

YADGARI L., KINREICH R., DRUYAN S., CAHANER A. (2006): The effects stocking density in hot conditions on growth, meat yield and meat quality of fetherless and feathered broilers. XII European Conference, Verona, Italy. World's Poultry Science Journal. Book of abstracts, 62, 603. 